\title{
Teaching writing through task-based instruction: Exploring English teachers' experiences
}

\author{
Laxman Prasad Bhandari \\ Lumbini Banijya Campus, Nepal \\ lpbhandari55@gmail.com
}

DOI: http://doi.org/ 10.36892/ijlls.v2i4.466

\begin{tabular}{|c|c|}
\hline $\begin{array}{l}\text { Recei } \\
04 / 10 /\end{array}$ & $\begin{array}{l}\text { Abstract } \\
\text { As educationists and policymakers have been concerned much in increasing }\end{array}$ \\
\hline & $\begin{array}{l}\text { the English proficiency of their citizens, educational policies on curriculums } \\
\text { and syllabuses have moved increasingly towards various versions of learner- } \\
\text { centered teaching approaches including task-based language teaching. TBLT } \\
\text { is one of the widely discussed learner-centered approaches for the last few }\end{array}$ \\
\hline $\begin{array}{l}\text { Keywords: } \\
\text { Teaching writing, } \\
\text { task-based } \\
\text { instruction, } \\
\text { English Curriculum, } \\
\text { Learner centeredness } \\
\text { English as a second } \\
\text { language }\end{array}$ & $\begin{array}{l}\text { decades. It aims at developing students' communicative skills through their } \\
\text { active engagement in various tasks focusing more on meaning than on form. } \\
\text { The study aims to explore English teachers' experiences in teaching writing } \\
\text { with respect to the intent of the secondary level English curriculum prescribed } \\
\text { by the Curriculum Development Center, Ministry of Education, Nepal. The } \\
\text { study is qualitative where five teacher participants were interviewed. The data } \\
\text { were analyzed based on the taxonomy of task types by Willis and Wills (2007). } \\
\text { The findings showed that the teacher participants are theoretically aware of } \\
\text { TBLT, especially in teaching writing, and the intent of the prescribed } \\
\text { curriculum; however, they are not able to fully bring their knowledge and } \\
\text { skills into practice to meet the objective of the curriculum. Thus, the study } \\
\text { purposes a way forward to strengthen teachers' ability to bring TBLT theory } \\
\text { into practice through training, workshops, research, and higher studies. }\end{array}$ \\
\hline
\end{tabular}

\section{INTRODUCTION}

English is taught as a compulsory subject starting from grade one in community schools and even before in the institutional schools up to grade twelve, and as a major subject in the higher level in the Nepalese context. The importance of learning English as a second language is, like in the global context, increasing in Nepal since the first English language education opened to the people in 1951. The school level of education consists of twelve years of education- five years of primary, three years of lower secondary, two years of secondary, and two years of higher secondary teaching (Bista, 2011). Though students learn English for twelve or even more years, their competency in this language is still low. Less emphasis on learner-centeredness has been given in delivering lessons in English classrooms, and Awasthi (2007) states most teachers are still using the traditional Grammar Translation (GT) method at all levels. Therefore, national policies and syllabuses have moved increasingly towards various versions of communicative language teaching including taskbased language teaching (Ellis, 2000) to increase the communicative efficiency of the students' in English(Al-Ghamdi, Almansoob \& Alrefaee, 2019). Hence, to develop students' English language efficiency, student-centered curriculums and syllabuses have been designed and implemented for the last few years in the Nepalese context as well. The curriculum has 
been designed in such a way that the learners are actively engaged to use all four-level language skills in a variety of personal, social, and academic contexts (CDC, 2014).

The study, therefore, explores teachers' experiences of TBLT focusing on five secondary level English teachers in Rupandehi, a district in the Terai region in Nepal. The study aims to explore whether teachers' experiences in teaching writing meet the intent of the prescribed curriculum. In doing so, this study intends to persuade teachers to take steps to better understand their beliefs about task-based language teaching and how their prior education and the restrictions of their teaching milieu may be affecting their teaching practice.

Despite there are a lot of useful studies, there is still a dearth of research exploring teachers' experiences regarding their use of task-based instruction in teaching writing in the Nepalese context. Therefore, the purpose of the study is to explore English teachers' experiences with respect to the intent of the present secondary level English curriculum prescribed by the Curriculum Development Center, Ministry of Education, Nepal. This study addresses the following research questions:

1. How do English teachers experience TBLT in teaching writing?

2. How do teachers' experiences align with the intent of the prescribed English curriculum in relation to teaching writing?

\section{LITERATURE REVIEW}

Task-based language teaching (TBLT) is one of the learner-centered approaches developed in the 1980s by N. S. Prabhu, a teacher and researcher in Bangalore, South India. It has been emerging as a learner-centered and experiential pedagogical approach arising from the practice of communicative language teaching (East, 2017). In this approach, teachers engage their students in both pedagogic as well as real-world tasks to develop their language skills so that they can develop skills in solving any language problem in their academic, social, and professional lives. Language teachers use this approach in developing their students' communicative skills through actively engaging them in listening, speaking, reading, and writing tasks. TBLT, as an approach, creates situations for interactions between students and teachers, and among students within the classroom setting. Unlike teachercentered approaches that primarily focus on the language form, TBLT focuses on the meaning of the language.

Task as a language activity aims at developing students' communicative skills focusing more on meaning than on form. Any activity given in the textbook may not meet the criteria for a language task rather it needs to foster learners' communication skills. Skehan (1998) points out that a task is a real-world activity in which meaning is primary and there is a real-world communication problem to solve. He also differentiates 'tasks' from 'exercises as (a) Orientation: communicative activities in tasks help to develop linguistics skills, but linguistic skills are regarded as the prerequisite for learning communicative abilities in exercises; (b) Focus: tasks focus on learning meaning while in exercises, linguistic form and semantic meaning are focused; (c) Goal: Tasks aim to foster communicative goal, while learners are expected to achieve code knowledge through exercises; (d) Outcome evaluation: teachers assess whether students have achieved communicative goals in tasks while the conformity of the code is assessed in exercises, and (e) tasks require natural communication while internalization of linguistic skills is emphasized in exercises. Hence, understanding of language tasks from the part of teachers is essential to develop language skills in the students.

For Ellis (2003), a task is a language learning activity that requires students to engage in the second language (L2) by focusing on meanings rather than in traditional grammar exercises. While working with tasks, learners concentrate more on meanings to fulfill the language of their real-life problems than the syntax of the language. Nunan (1989) defines a 
communicative task as a piece of a classroom activity that engages learners in understanding, manipulating, creating, or interacting in the target language. Similarly, Rolin-lanziti (2014) states that a task has to be a language resource to create opportunities for learners to communicate in a second language (L2). Thus, any activity or a piece of work that helps students develop both fluency and competency of a language when they get engaged (Yassin, Razak, \& Maasum, 2018).

Most researchers agree that the use of tasks makes language learning more studentcentered and communicative. Language tasks can vary from simply listing things required for a recipe to complex problem-solving, and they are designed and implemented based on the learners' needs, interests, and learning abilities. Prabhu (1987) proposes three types of language tasks: information-gap activities, reasoning-gap activities, and opinion-gap activities to solve language problems. To foster language skills in all kinds of learners, from children to adults or dull to bright, Willis (1996) purposes six types of tasks as listing, ordering and sorting, comparing, problem-solving, sharing personal experiences, and creative tasks. These tasks are designed based on the intent of the prescribed curriculum and the learning level and interest of the students. Similarly, Ellis and Shintani (2014) categorize language tasks into focused and unfocused tasks. It is teacher's job, as Bhandari (2020) states, to select appropriate tasks and sequence them in such a way that best fit his or her students' learning abilities and meet the expectation of the curriculum.

Language tasks engage students in pairs or groups where each of the students is expected to participate in contributing to complete the task assigned. Even shy and slow learners do not feel hesitation in learning from their more active and quick peers and vice versa while working in pairs or groups. Therefore, language learning is a process whereby knowledge is socially co-constructed through interactions (Vygotsky, 1978). All these tasks have a common aim to develop communicative competence in the learners if they are well designed, sequenced, and implemented. Following Vygotsky's socio-cultural theory, Fahim and Haghani (2012) emphasize the role of people's (especially adult) participation through the Zone of Proximal Development (ZPD) for the mastery of the language. TBLT emphasizes that the students are exposed to tasks which they accomplish by discussing, interacting, and negotiating with their peers in pairs or groups, or with their teacher. The concept of ZPD also states that the more knowledgeable.

\section{Task-based Language Teaching and Teaching Writing}

Writing is one of the four important language skills and a significant aspect of English proficiency. Writing helps students construct and co-construct their identities as insiders, outsiders, and travelers to other members of the academic community (Cui, 2019). However, Purwanto (2016) states it is still considered supplementary as compared to the other language skills among second or foreign language learners. Language teachers spend most of their class hours dictating essays, letters, and question-answers, etc. in their writing classes rather than engaging students in interactive writing tasks. As a result, the students, too, do not take writing seriously until they approach the examinations. In this regard, Najla-Maria Riad (2015) states that there is a decrease in the learners' motivation to write and create writing of their own at this stage as well as a decline in teacher-creativity in the classroom. Students are often just assigned some writing tasks or exercises as homework, and they are evaluated through written examinations to decide whether to upgrade them or not.

Writing should occur in a setting where enough time is being allotted for writing tasks, where students interact with their peers in pairs or groups, negotiate and come up with some solution to a communicative problem, and the teacher facilitates students more on a one-to-one basis rather than in a lecturing mode (Hawthorne, 2007). The CDC (2014) also emphasizes on teaching writing descriptive, narrative, and imaginative texts, in a range of 
different forms and media with a fair degree of accuracy, and appropriate writing tasks, if implemented properly, can meet this expectation of the prescribed curriculum.

\section{Task-Based Lessons}

Task-based language teaching (TBLT) constitutes both a state-of-the-art language teaching approach and a promising area of investigation in the field of second language acquisition (SLA) (Ahmadian, 2016). Language learning is meaningful when tasks are designed based on the students' level, interest and need, and implemented effectively. Thus, teachers should not merely choose a topic from the textbook but can also ask their students to suggest their own topics from a list provided to them. CDC (2014) emphasizes the use of pair and group works in fostering high levels of students' participation and language use, and thus teachers are suggested to organize most lessons around both full classwork and opportunities for pair and group work.

The present curriculum has been designed to scaffold students' language learning through the careful design of follow-up tasks that create opportunities for them to practice in authentic contexts. In this regard, Willis and Willis (2007) state that an appropriate task generates both interest and opportunities as well as challenges for learners to participate in language use. Willis and Wills suggest that there should be a good sequence of various tasks, one related to the other, to reach an outcome or the objective of the lesson. After a topic is finalized, teachers can set up different types of tasks that are classified according to cognitive processes (Table 1).

Table 1: Taxonomy of task types in Willis and Willis (2007)

\begin{tabular}{|l|ll|}
\hline Listing & $\begin{array}{l}\text { Brainstorming; Fact-finding; Games based on listing: } \\
\text { quizzes, memory, and guessing }\end{array}$ \\
\hline Ordering and sorting & Sequencing; Ranking ordering; Classifying & \\
\hline Comparing and contrasting & $\begin{array}{l}\text { Games finding similarities and differences; Graphic } \\
\text { organizers }\end{array}$ \\
\hline Problem-solving tasks & Logic problem prediction \\
\hline Project and creative tasks & Newspapers; Posters; Survey fantasy, etc. & \\
\hline Sharing personal experiences & Storytelling; Anecdotes; Reminiscences \\
\hline Matching & Words and phrases to pictures \\
\hline
\end{tabular}

Though there have been discussions on learner-centeredness in language teaching and learning, most of the studies cited thus far have focused on the effectiveness of interaction itself for the collaborative buildings of meanings, i.e., on the joint interaction that develops as learners co-construct meanings (Lantolf, 2000). Less space has been devoted to the relationship between teachers' understanding and practices (experiences) regarding teaching writing through TBLT in connection with the prescribed curriculum in our context.

\section{METHOD}

\section{Research context}

The study was conducted at two community secondary level schools in Rupandehi district, in the southwestern part of Nepal. The main course objective is to help students develop accuracy and fluency in writing, which constitutes 35 percent of the total teaching hours. As I experienced that writing is a challenging language skill for most Community school students in Nepal. 


\section{Participants}

Five secondary level teachers were purposively selected based on their teaching experience, knowledge of the research phenomenon, and their readiness to engage in sharing their experiences during the in-depth interviews.

\section{Data Collection, instruments and analysis}

To explore teachers' experiences, unstructured interviews, using open-ended questions, were performed with each participant to explore their voices, stories, and experiences with the research phenomenon. Although I intended to exploit both interviews and observation (of their classes), I was confined to only virtual (via telephone, Zoom, Google Meet, and Viber) interviews because of the fear of the spread of the pandemic coronavirus (COVID-19) and the nationwide lockdown in Nepal which was implemented since March 24, 2020, affecting my research area as well for long.

The saturated data were obtained after prolonged engagement with each participant at different times. The interviews were conducted in each participant and the researcher's mother tongue, i. e. Nepali language and the interviews were video-recorded with the laptop and cell phone. I adopted the thematic analysis guide, defined by Braun and Clarke (2006), to elicit, analyze and report themes and patterns within the collected information. The findings were drawn through the process of transcribing the interview data and noting down initial thoughts, coding the important features of the data systematically, collating codes into potential themes, reviewing the themes for suitability across all coded extracts, generating clear definitions and names for each theme, and selecting the most compelling extracts related to the research questions and relevant literature. This method allows for a flexible, detailed, and complex description of the data.

\section{RESULTS AND DISCUSSION}

The findings of the study are organized into two themes based on the interpretation and analysis of the data collected from the research participants through the interviews. The first theme 'Teachers' experiences of TBLT in teaching writing' is about how they select and design, and sequence tasks for teaching writing to meet the intent of their prescribed curriculum, and the second theme on 'Alignment of teachers' experiences of TBLT with the intent of the curriculum' deals with how teachers' knowledge and experiences of TBLT help them meet the intent of the English curriculum prescribed in the secondary level.

\section{Teachers' experiences of TBLT in teaching writing}

Good exposure to student-centered teaching approaches during pre-service teacher education influences teachers' performance in their profession. Since the research participants were exposed to various communicative language teaching approaches and methods during their university studies, they have a considerable amount of knowledge, and they (Lin \& Wu, 2012) hold positive perceptions towards task-based language teaching. In this regard, Teacher-C stated, "I studied Master in Education (M. Ed.) in English, so I learned much about student-centered teaching. I learned the theory of TBLT at university, now I am trying to implement it here." When she was further inquired if a fifteen-day microteaching and a forty-five-day teaching practice as components of her evaluation in the university helped her implement tasks in her professional classrooms, she commented, "No, our teacher called us only for two days for micro-teaching, and he gave us instructions. And we completed teaching practice in fifteen to twenty days. I started using TBLT learning from colleagues." Her experience with the micro-teaching and teaching practice during their Master of Education (M. Ed.) was similar to all other participants of the study. In this line, Teacher-E added, "Our teacher asked us to prepare 45 lesson plans and submit them as a practicum. I only learned using writing activities in class when I started teaching." As 
Suhendi and Purwarno (2018) explored that learning takes place through interactions with peers, teachers, and the world-at-large, the teachers reported that they learned to select, design, and implement writing tasks by learning from each other and participating in training and workshops. However, the participants also stated that they learned to be student-centered when the new course objective required them to engage students in various writing activities both from their textbooks and their everyday world.

CDC (2014) suggests designing and implementing tasks to help students write for a variety of audiences, purposes, and in various forms to communicate meaning, ideas, and emotions. The participants also exhibited similar knowledge regarding writing task selection, designing, and implementation in their class. In this respect, Teacher-B commented: "There are good writing tasks in the textbooks, and I use them." The curriculum has been designed in such a way that textbook writers have also included ample tasks for teaching language skills in general and teaching writing specifically. They experienced that their students were more motivated towards writing their own stories relating to the text they read in their textbooks. Teacher-D commented, "My students love writing about their families, friends and festivals. I see some of them feel proud to help their peers, and others enjoy writing with their peers than with me." Their experience goes in line with Vygotsky's (1986) concept of the zone of proximal development (ZPD) where learning occurs when students work on tasks within reach of their abilities.

In addition to the tasks given in the textbooks, teachers also design and implement language tasks in their writing classes. Teacher-B, in this regard, stated: "I also prepare tasks like, umm...writing their (students') travel or sports experiences. Sometimes I take an advertisement from the Newspaper, and ask them to write a job application letter, resume, appointment letter, and resignation letter." Students' engagement in different tasks enhances their writing. This follows the task taxonomy of Willis and Willis (2007) in which all types of tasks from simply listing to more complex creative and problem-solving tasks are suggested. In this line, Teacher- A also added: "I, first, select or prepare easier tasks like matching or listing, and then slowly move towards more complex ones in which the students work more in pairs and groups to complete their writing tasks."

Working in pairs and groups helps students learn without hesitation. In line with ZPD, Teacher-B said, "My students complete some tasks themselves, and they help one another for some tasks in pairs and groups, and I help them with some tasks. So, they learn easier to more difficult writing exercises." Students feel more comfortable learning from each other, and if they feel difficulty, the teacher assists them to learn in task-based teaching.

The teachers experienced that the more the students get engaged in writing tasks whether in pairs or groups, the more they develop their writing skills. Their experience goes along with the findings of Kafipour, et al. (2018) who stated that tasks improve EFL learners' ability in writing competence which includes sentence mechanics, language use, vocabulary, content, and organization along with fulfilling a specific communicative purpose.

\section{Alignment of teachers' TBLT experiences with the intent of the curriculum}

Task-based language teaching aims to engage students in various tasks to enhance their language efficiency. Writing tasks are matched with the students' corresponding level according to achieve the aim of the curriculum (Elshoff, 2014). Accordingly, the study explored the teachers' experiences of teaching writing to meet the expectation of the curriculum. Teacher-A stated, "I use all the textbook activities and tasks in teaching writing because they are designed to meet the aim of the curriculum. Also, I design some tasks to make my class more interactive." Engagement in tasks develops students' confidence to communicate effectively in English (CDC, 2014). 
TBLT in a communicative setting is at the center of the way the curriculum has been designed and developed. The finding connects with the idea of Ellis (2000) who mentions, TBLT is on the way the students collaborate to scaffold each other's attempt to perform functions that lie outside their individual abilities. In this regard, Teacher-B stated, "I divide the class into different groups with mixed ability students. The brighter ones help slow learners when they face difficulties, and they come to me for more difficult tasks." In support of this statement, Vygotsky (1986) states the real learning when they collaborate with their peers in pairs and groups.

The curriculum and teaching-learning strategies should address the level, need, and interest of the students. The curriculum anticipates student-friendly learning facilitation (CDC, 2014). The curriculum should be designed and implemented for the development of new course materials (Elshoff, 014). The study explored that teachers design different tasks in addition to implementing the writing tasks given in the textbooks to encourage students' collaborative practices. With this respect, Teacher-B commented, "There are sufficient writing tasks in the textbooks. Each of my students gets a chance to express their ideas in writing. Yes, they also enjoy working with others in the groups." Similarly, Teacher-A added, "Once one of my shy students wrote a recipe of a meal wonderfully asking with his mother." Students learn more from their real-life experiences than from classroom teaching.

The English curriculum aims to help students write descriptive, narrative, and imaginative texts, in a range of different forms and media with a fair degree of accuracy (CDC, 2014) which are addressed through the use of various tasks- information-gap tasks, reasoning tasks, and opinion-gap tasks (Prabhu, 1987); focused and unfocused tasks (Ellis \& Shintani, 2014), and those discussed by Willis and Willis (2007). In this regard, Teacher-B stated, "The curriculum includes all types of tasks for developing writing skill in the students." However, he further commented, "I have very limited time to complete the course. You know, the students should stay silent throughout the class. If your students make a noise, they will call you to the office for justification." In spite of the various uses of TBLT, the teachers also experienced some challenges in designing and implementing tasks in teaching writing. Thus, to teach a lesson practically with task-based, Hashemi, et al. (2012) state, it involves consideration of the stages or components of a lesson that has a task as its principal component.

\section{CONCLUSION}

Since the importance of task-based language teaching has been felt by ELT practitioners, policymakers and curriculum designers, the emphasis on including various tasks for teaching English has been prioritized in the syllabuses. This paper explored English teachers' practices and experiences of TBLT for improving the secondary level students' writing skills. Since the curriculum aims at developing students' skills to write descriptive, narrative and imaginative texts, in a range of different forms and media with accuracy (CDC, 2014), teachers implement tasks-based teaching based on the need, level and interest of the students.

The study aimed at exploring English teachers' experiences in teaching writing with respect to the intent of the secondary level English curriculum. It started with the exploration of TBLT and teaching writing in connection with the curriculum. As the data were analyzed based on the taxonomy of task types (Willis \& Willis, 2007), it elicited that the teachers employ both tasks from their textbooks as well as their self-designed tasks to develop writing in their students. The pre-service teacher education helped them develop theoretical knowledge of task-based teaching, student-centeredness and their roles as task-based 
teachers; however, they experienced its practice only after they started the profession. The findings also revealed that they experienced their students learning better from their peers in pairs and groups than from the teacher-centered classes.

The findings revealed that though the teachers are well aware of theoretical aspects of TBLT and teaching writing, they need more exposure to fully bring their theoretical knowledge of TBLT including the designing, sequencing and implementing tasks in teaching writing effectively to achieve the objective of the curriculum prescribed in the secondary level. Thus, the study purposes a way forward to develop teachers' skills to employ TBLT in teaching writing through training, workshops, research, and higher studies.

\section{REFERENCES}

Ahmadian, M. J. (2016) Task-based language teaching and learning. The Language Learning Journal, 44(4), 377-380.

Al-Ghamdi, N., Almansoob, N., \& Alrefaee, Y. (2019). Pragmatic Failure in the Realization of the Speech act of Responding to Compliments among Yemeni EFL

Undergraduates. 3L: Language, Linguistics, Literature. 25(4), 227-240. doi:10.17576/31-2019-2504-14.

Awasthi, J. R. (2007). Second language acquisition: Where we are heading to. Journal of NELTA, 12(1-2), 13-17.

Bhandari, L. P. (2020). Task-based language teaching: A Current EFL approach. Advances in Language and Literary Studies, 11(1), 1-5.

Bista, K. (2011). Teaching English as a foreign/second language in Nepal: Past and present. English for Specific Purposes World, 11(32), 1-9.

Braun, V. \& Clarke, V. (2006). Using thematic analysis in psychology. Qualitative Research in Psychology, 3(2), 77-101.

Cui, W. (2019). L2 writers construct identity through academic writing discourse socialization. Journal of English as an International Language. https://files.eric.ed.gov/fulltext/EJ1244672.pdf

Curriculum Development Centre (CDC) Nepal. (2014). Secondary education curriculum of Nepal (class 9-10). Sanothimi: Author.

East, M. (2017). Research into practice: The task-based approach to instructed second language acquisition. Cambridge University, 50(3), pp. 412-424.

Ellis, R. (2000). Task-based research and language pedagogy. Language Teaching Research. 4(193), 193-220.

Ellis, R. (2003). Task-based language learning and teaching. Oxford University Press.

Ellis, R., \& Shintani, N. (2014). Exploring language pedagogy through second language acquisition research. Rutledge.

Elshoff, J. (2014). Designing a task-based curriculum for intensive language training. In S.

Jager, L. Bradley, E. J. Meima, \& S. Thouësny (Eds), CALL Design: Principles and Practice; Proceedings of the 2014 EUROCALL Conference, Groningen, The Netherlands (pp. 65-71). Dublin: Research-publishing.net. 
Fahim, M. \& Haghani, M. (2012). Sociocultural perspectives on foreign language learning. Journal of Language Teaching and Research, 3(4), 693-699.

Hashemi, M., Azizinezhad, M. \& Darvishic, S. (2012). Procedia-Social and Behavioral Sciences, 31, 526-529.

Hawthorne, S. (2007). How best to teach writing skills: A review of the research into effective ways of teaching writing. English In Aotearoa, 62, 27-35.

Kafipour, R., Mahmoudi, E. \& Khojasteh, L. (2018) The effect of task-based language teaching on analytic writing in EFL classrooms, Cogent Education, 5(1), pp. 1-16.

Kandel, P. B. (2013). Effectiveness of task-based language teaching in developing writing skills at the secondary level in Nepal [Unpublished Ph. D. thesis, The English and Foreign Languages University, Hyderabad, India].

Lantolf, P. J. (Ed.). (2000). Sociocultural theory and second language learning. Oxford: OUP.

Lin, T. B., \& Wu, C. W. (2012). Teachers' perceptions of task-based language teaching in English classrooms in Taiwanese junior high schools. TESOL Journal, 3(4), 586-609.

Najla-Maria Riad, M. (2015). Teaching writing in secondary schools: An exploratory study of Lebanese private schools. [Master of Arts in Education Thesis]. Lebanese American University. http://hdl.handle.net/10725/2706

Nunan, D. (1989). Designing tasks for the communicative classroom. Cambridge University Press.

Prabhu, N. S. (1987). Second language pedagogy. Oxford University Press.

Purwanto, S. (2016). Improving academic writing skills through online mode of task-based assignments. English Language Teaching, 9(9), 74-84.

Rolin-Ianziti, J. (2014). The Conversational Outcomes of Task Implementation. Open Journal of Modern Linguistics, 4, 100-117.

Skehan, P. (1998). Task-based instruction. Annual review of applied linguistics, 18, 268-286.

Suhendi, A. \& Purwarno. (2018). Constructivist learning theory: The contribution to foreign language learning and teaching in the 1st annual international conference on language and literature, KnE social sciences, 87-95.

Vygotsky, L. (1978). Mind in society. In M. Cole, V. J. Steiner, S. Scribner \& E. Souberman (Eds.). Harvard University Press.

Vygotsky, L. (1986). Thought and language. In A. Kozulin (Ed.). The MIT Press.

Willis, J. (1996). A framework for task-based learning. Longman.

Wills \& Willis (2007). Doing task-based teaching. Oxford University Press. 
Yassin, A. A., Razak, N. A., \& Maasum, T. N. R. T. M. (2018). Cooperative learning: general and theoretical background. Advances in Social Sciences Research Journal, 5(8).

\section{$\underline{\text { AUTHORS'BIO }}$}

Laxman Prasad Bhandari, an MPhil Scholar at Kathmandu University, is an assistant professor in English Language Education at Lumbini Banijya Campus, Butwal, Nepal. His research interests are the task-based approach to English language teaching, technology-based language teaching methodologies, second language acquisition and qualitative research methodologies. 